Hal 19-24

\title{
PENERAPAN POSISI SEMI FOWLER TERHADAP KETIDAKEFEKTIFAN POLA NAFAS PADA PASIEN CONGESTIVE HEART FAILURE (CHF)
}

\author{
Ahmad Muzaki ${ }^{1}$, Yuli Ani ${ }^{2}$ \\ Akademi Keperawatan Pemkab Purworejo \\ Purworejo, (0275) 3140576 \\ E-mail : muzaki.ahmad1@yahoo.com
}

\begin{abstract}
ABSTRAK
Latar Belakang : Congestive Heart Failure atau lebih sering dikenal dengan penyakit gagal jantung adalah penyakit sindrom klinis yang ditandai dengan sesak nafas saat istirahat atau saat aktivitas yang disebabkan oleh kelainan struktur atau fungsi jantung. Klien CHF dengan ketidakefektifan pola nafas perlu diberikan posisi semi fowler. Tujuan: diberikan posisi ini untuk menurunkan konsumsi oksigen dan meningkatkan ekspansi paru yang maksimal, sehingga ketidakefektifan pola nafas klien lebih optimal pada pasien CHF di RSUD Wates. Metode: Jenis penelitian ini adalah deskriptif dengan menggunakan metode pendekatan studi kasus. Subjek dalam studi kasus ini adalah dua orang pasien yang terkena CHF dengan ketidakefektifan pola nafas. Intervensi semifowler position dilakukan dimana posisi kepala dan tubuh dinaikkan dengan $45^{\circ}$. Hasil: Penerapan posisi semi fowler (posisi duduk $45^{\circ}$ ) selama 3x24 jam sesuai dengan SOP membantu mengurangi sesak nafas dan membantu mengoptimalkan RR pada klien sehingga masalah ketidakefektifan pola nafas dapat teratasi. Kesimpulan: Intervensi pengaturan sudut posisi tidur secara bermakna dapat menghasilkan respirasi yang baik, sehingga bisa dipertimbangkan sebagai salah satu intervensi untuk mengoptimalkan ketidakefektifan pola nafas.
\end{abstract}

Kata Kunci: Posisi Semifowler, Posisi Tidur 45, Congestive Heart Failure

\begin{abstract}
Background : Congestive Heart Failure or more commonly known as Heart failure is a disease of clinical syndrome that is characterized by shortness of breath and fatique at rest or during activities caused by structural abnormalities or heart function. CHF patients with ineffective breathing patterns need to be given a semifowler position. Objective: is given this position to decrease oxygen consumption and increase maximal lung expansion, so the ineffectiveness of the client breathing pattern is more optimal CHF patients at RSUD Wates. Method: This type of research is descriptive using case study approach method. Subjects in this case study were two patients who had CHF patient with ineffective breathing pattern. Semifowler interventions is given where the position of the head and body is increased with declivity $45^{\circ}$. Results: The application of semi-fowler position (sitting position $45^{\circ}$ ) for $3 \times 24$ hours in accordance with the SOP helps reduce shortness of breath and helps optimize RR on the client so that the problem of ineffective breathing patterns can be overcome. Conclusion: Significant sleep angle adjustment interventions can produce good respiration, so it can be considered as one of the interventions to maximize the ineffectiveness of breathing patterns.
\end{abstract}

Keyword: Semifowler Position Sleep Position 45, Congestive Heart Failure 


\section{Latar Belakang}

Congestive Heart Failure (CHF) merupakan satu-satunya penyakit kardiovaskuler yang terus meningkat insiden dan prevalensinya. Resiko kematian akibat gagal jantung berkisar antara 5-10\% pertahun pada kasus gagal jantung ringan dan meningkat menjadi $30-40 \%$ pada kasus gagal jantung berat. Selain itu, gagal jantung merupakan penyakit yang paling sering memerlukan perawatan ulang dirumah sakit (readmission) meskipun pengobatan rawat jalan diberikan secara optimal (Kasron, 2012).

Angka kejadian gagal jantung semakin meningkat dari tahun ketahun, Data yang diperoleh dari WHO (2013) ada 17,3 juta orang meninggal akibat gangguan kardiovaskular pada tahun 2008 dan lebih dari 23 juta orang akan meninggal setiap tahun dengan gangguan kadiovaskular. Kejadian gagal jantung di Amerika Serikat mempunyai insidensi yang besardan tetap stabil selama beberapa dekade terakhir, yaitu $>650.000$ kasus baru didiagnosis setiap tahunnya.

Di Indonesia berdasarkan dari data Kemenkes (2014) diagnosis dokter pada tahun 2013 untuk penderita gagal jantung berdasarkan diagnosis/gejala, Provinsi Jawa Tengah menempati peringkat ke 3 diagnosis/gejala, estimasi jumlah penderita gagal jantung yaitu sebesar 72.268 orang (0,3\%) (dikutip dalam Nurlaela, 2017).

Data prevalensi didapat saat penelitian di RSUD Wates pada tahun 2018 mencapai $0,32 \%$ atau seratus tujuh puluh sembilan orang, dan pada tahun 2019 hingga bulan Juni data yang masuk menurun yaitu hanya $0,12 \%$ atau 44 orang (Rekam Medic RSUD Wates, 2019).

Gagal jantung menimbulkan berbagai gejala klinis, yang paling dirasakan adalah sesak nafas pada malam hari dan sering muncul tiba-tiba yang menyebabkan pasien terbangun. Gagal jantung adalah sindrome klinis yang ditandai dengan sesak nafas dan fisik (saat istirahat atau aktivitas) yang disebabkan oleh kelainan struktur atau fungsi jantung. Gagal jantung dapat disebabkan oleh gangguan yang mengakibatkan terjadinya pengurangan ventrikel (disfungsi diastolik) dan kontraktilitas miokardial (disfungsi sistolik) (Nurarif \& Kusuma, 2015).

Posisi adalah tindakan yang dilakukan dengan sengaja untuk memberikan posisi tubuh dalam meningkatkan kesejahteraan atau kenyamanan fisik dan psikologis. Aktivitas intervensi keperawatan yang dilakukan untuk pasien gagal jantung diantaranya menempatkan tempat tidur yang terapeutik, mendorong pasien meliputi perubahan posisi, memonitor status oksigen sebelum dan setelah perubahan posisi, tempatkan posisi dalam posisi terapeutik, posisikan pasien dalam kondisi body aligemnent, posisikan untuk mengurangi dyspnea seperti posisi semi-fowler, tinggikan $45^{\circ}$ atau lebih diatas jantung untuk memperbaiki aliran balik.

Mengatur pasien dalam posisi tidur semi fowler akan membantu menurunkan konsumsi oksigen dan meningkatkan ekspansi paru-paru maksimal serta mengatasi kerusakan pertukaran gas yang berhubungan dengan perubahan membran alveolus. Dengan posisi semi fowler, sesak nafas berkurang dan sekaligus akan 
meningkatkan durasi tidur klien (dikutip dalam Melanie, 2014)

Berdasarkan latar belakang di atas, maka penulis mencoba memaparkan Penerapan Posisi Semi Fowler Terhadap Ketidakefektifan Pola Nafas Pada Pasien Congestive Heart Failure (Chf)

\section{Metode}

Desain penelitian ini adalah deskriptif, dalam bentuk studi kasus. Penelitian diarahkan untuk mendeskripsikan penerapan posisi semi fowler terhadap ketidakefektifan pola nafas pada pasien Congestive Heart Failure (CHF) di ruangan ICCU selama 3 hari. Subyek dala penelitian ini adalah dua orang klien yang mengalami gagal jantung kongestif dengan kriteria mengalami sesak nafas dan kesadaran composmentis.

Pelaksanaan pengumpulan data dilakukan di ICCU RSUD Wates. Waktu penelitian studi kasus ini dimulai pada tanggal 24 Juni 2019 sampai 30 Juni 2019.

Pengumpulan data tentang pemberian posisi semi fowler terhadap ketidakefektifan pola nafas pada pasien Congestive Heart Failure (CHF), yaitu:

1. Observasi

Dalam penelitian ini, penulismengobservasi atau melihat keadaan umum partisipan dengan pemeriksaan fisik (dengan pendekatan IPPA : inspeksi, palpasi, perkusi, dan auskultasi).

2. Pengukuran

Dalam penelitian ini, penulismengukur menggunakan alat ukur pemeriksaan, seperti melakukan pengukuran tekanan darah, menghitung frekuensi napas, dan menghitung frekuensi nadi, frekuensi nafas (RR). Penulis menggunakan beberapa peralatan yang akan digunakan dalam proses pengumpulan data yaitu tensimeter jarum, stetoskop, jam tangan dan alat tulis.

3. Wawancara

Dalam penelitian ini wawancara yang dilakukan dengan menggunakan wawancara. Wawancara jenis ini merupakan kombinasi dari wawancara tidak terpimpin dan wawancara terpimpin.

4. Dokumentasi

Dokumentasi yang dilakukan oleh penulisyaitu pendokumentasi hasil pengkajian, analisa data, diagnosa keperawatan, rencana keperawatan, tindakan keperawatan, dan evaluasi dari tindakan.

Instrumen pengumpulan data yang meliputi:

1. Memasang posisi semi fowler sesuai SOP Rumah Sakit.

2. Pedoman observasi respiratory rate (RR) atau frekuensi nafas.

Uji keabsahan data dimaksudkan untuk menguji kualitas data atau informasi yang diperoleh dalam penelitian sehingga menghasilkan data dengan validitas tinggi. Triangulasi dalam penelitian ini menggunakan triangulasi observasi, yaitu hasil pengukuran respiratory rate post test dan triangulasi waktu, yaitu dilakukan dengan mengukur respiratory 
rate setelah diberikan posisi semi fowler

\section{Hasil}

Tn. A tanggal 24 Juni 2019 pukul 08.00 WIB di ruang ICCU RSUD Wates dengan diagnosa $\mathrm{CHF}$ didapatkan klien mengeluh sesak nafas, sesak bertambah saat berbaring, klien mengatakan mudah lelah saat beraktivitas, klien mengatakan lemas, pusing, dan klien mengatakan sesekali terbangun saat tidur karena sesak, tanda-tanda vital: TD: 104/61mmHg, MAP: 76x/m RR; 29x/m Nadi: 55x/m, $\mathrm{SpO}_{2}: 96 \%$, suhu: $36,2^{\circ} \mathrm{C}$, hasil EKG sinus bradikardi, hasil rontgen thorax cardiomegali, terpasang kanul nassal $\mathrm{O}_{2} 31 \mathrm{pm}$, akral dingin, ADL sepenuhnya dibantu oleh perawat.

Sementara hasil pengkajian pada Tn. S tanggal 27 Juni 2019 pukul 19.00 WIB di ruang ICCU RSUD Wates dengan diagnosa CHF didapatkan klien mengeluh sesak nafas, klien mudah lelah saat beraktivitas, badan terasa lemas, dan ADL klien dibantu sepenuhnya oleh perawat, hasil EKG atrial fibrilasi, hasil rotgen thorax cardiomegali dan kedua apeks pulmo tenang, terpasang kanul nassal $\mathrm{O}_{2} 3 \mathrm{lpm}$, akral dingin, tanda-tanda vital: TD: 121/78mmHg, MAP: 71x/m, RR: 28x/m Nadi: $86 x / m, \mathrm{SpO}_{2}: 97 \%$, suhu: $36,1^{\circ} \mathrm{C}$

Padai Hari pertama penulis mengukur kedalaman pernafasan pada Tn. A dan Tn. S. Pada Tn. A ditemukan pernafasan dangkal dan sesak nafas RR: 29x/m dan tidak ada suara nafas tambahan pada kedua klien, sedangkan pada Tn. S ditemukan pernafasan dangkal dengan RR: 28x/m dan kedua klien sama-sama terpasang kanul nassal dengan konsentrasi 3lpm. Setelah itu penulis memberikan posisi semi fowler untuk membantu memaksimalkan ventilasi dan meminimalkan penggunaan oksigen bagi klien sehingga sesak nafas yang rasakan dapat berkurang dan klien dapat tidur dengan nyenyak, serta RR menjadi dalam batas normal (16- $24 x / m)$.

Pada hari ketiga evaluasi hari ketiga penulis melakukan motoring pernafasan didapatkan data Tn. A, S: Klien mengatakan sesak berkurang $\mathrm{O}$ : $\mathrm{Ku}$ sedang, klien rileks, posisi klien semifowler, GCS: 15 (E4,V5,M6) RR: 24x/menit, $\mathrm{SpO}_{2}$ : 99\%, $\mathrm{FiO}_{2}$ : 3 1/menit. Sedangkan pada Tn Tn. S, S:Klien mengatakan sudah tidak sesak, O:Ku baik, klien rileks, posisi klien semifowler, RR: 18x/menit, SpO2: 99\%, klien sudah tidak memakai kanul nassal,

Berdasarkan hasil observasi yang didapatkan dari Tn. P dan Tn S. maka penulis mengambil kesimpulan setelah diberikan posisi semi fowler 45 derajat, RR dalam batas normal: $(16-24 x / m)$, klien menunjukkan jalan nafas yang paten, tidak sianosis dan klien mengatakan sudah tidak sesak nafas.

\section{Pembahasan}

1. Gambaran frekuensi nafas (RR) sebelum diberikan posisi semi fowler

Pada klien didapatkan bahwa bahwa sebelum diberikan posisi semi fowler pasien RR meengalami peningkatan. Pada Tn. A ditemukan pernafasan dangkal dan sesak nafas RR: $29 x / m$. Tn. S ditemukan pernafasan dangkal dengan RR: 28x/m dan kedua klien sama-sama terpasang kanul nassal dengan konsentrasi 31pm. 
Menurut (Melanie, 2014) bahwa pasien dengan CHF akan mengalami sesak napas yang akan mengganggu ketidakefektifan pola napas klien dengan manifestasi yang ditandai dengan dyspnea, RR klien meningkat (normal RR 16-24 x/menit).

Menurut penulis sesak nafas yang terjadi pada Tn. A RR: 29x/m dan Tn. S. 28x/m merupakan respon dari ketidakefektifan pola napas yang disebabkan oleh pembesaran pada jantung atau cardiomegali yang menyumbat dan membuat darah tidak dapat memompa secara adekuat untuk memenuhi kebutuhan tubuh, dan akan mengganggu klien Tn.A dan Tn. S. hal ini sesuai teori diatas bahwa pasien CHF mengalami ketidakefektifan pola nafas.

2. Gambaran frekuensi nafas (RR) setelah diberikan posisi semi fowler

Setelah diberikan posisi semi foler 45 derajat maka pada kedua klien sesak nafas berkurang dengan RR dalam batas normal, tidak ada cuping hidung dan sudah tidak terpasang nasal kanul.

Positioning adalah tindakan yang dilakukan dengan sengaja untuk memberikan posisi tubuh dalam meningkatkan kesejahteraaan atau kenyamanan fisik dan psikologis. Posisi semi fowler adalah posisi dimana kepala dan tubuh dinaikan dengan derajat kemiringan $45^{\circ}$ (Melanie, 2014).

Pemberian posisi semi fowler 45 derajat pada pasien CHF dimasksudkan untuk mengurangi sesak nafas, menurunkan RR dalam batas normal dan serta meningkatkan rasa kenyamanan. Hal ini sesuai dengan teori Melanie, (2014)
Klien dengan penyakit kardiopulmonal yang mengalami keluhan sesak, tidak dapat tidur dalam posisi berbaring melainkan harus dalam posisi duduk atau setengah duduk.

Menurut Melanie, (2014) rencana keperawatan pada diagnosa keperawatan ketidakefektifan pola nafas adalah pemberian posisi semifowler. Tujuan dari tindakan memberikan posisi tidur Semi fowler adalah untuk menurunkan konsumsi oksigen dan meningkatkan ekspansi paru yang maksimal, serta untuk mengatasi kerusakan pertukaran gas yang berhubungan dengan perubahan membran kapiler alveolus. Pada pasien Tn. A dan Tn. $\mathrm{S}$ penulis mencantumkan rencana keperawatan posisi semifowler untuk membantu mengurangi sesak nafas pada kedua klien mengoptimalkan RR pada klien.

Posisi semi fowler (posisi duduk $45^{\circ}$ ) selama $3 \times 24$ jam sesuai dengan SOP yang ada, tujuan diberikan posisi semi fowler adalah membantu mengurangi sesak nafas dan membantu mengoptimalkan RR pada klien.

Menurut Melanie

pemberian posisi semi fowler pada klien akan mengakibatkan peningkatan aliran balik ke jantung tidak terjadi secara cepat. Aliran balik yang lambat maka peningkatan jumlah cairan yang masuk ke paru berkurang, sehingga udara di alveoli mampu mengabsorbsi oksigen. 


\section{Kesimpulan}

Berdasarkan penjelasan di atas, dapat disimpulkan bahwa penerapan posisi semi fowler (posisi duduk $45^{\circ}$ ) selama $3 \times 24$ jam sesuai dengan SOP membantu mengurangi sesak nafas dan membantu mengoptimalkan RR pada klien sehingga masalah ketidakefektifan pola nafas dapat teratasi.

\section{Ucapan Terima Kasih}

Dalam hal ini penulis mengucapkan terima kasih kepada Direktur Akper Pemkab Purworejo dan Ketua Lembaga Penelitian dan Pengabdian Masyarakat yang telah memberikan dukungan moril maupun materiil dalam penyelesaian publikasi ini.

\section{Daftar Pustaka}

Asmadi. (2009). Teknik Prosedural Konsep \& Aplikasi Kebutuhan Dasar Klien Google Books. In Hartiah Haroen (Ed.), ebook (p. 188). Jakarta.

Aspiani, Y., R (2014). Buku Ajar Asuhan Keperawatan Klien Gangguan Kardiovaskuler : Aplikasi NIC \& NOC. Jakarta: Buku Kedokteran EGC

Kasron, (2012). Buku Ajar : Gangguan Sistem Kardiovaskuler. Yogyakarta: Nuha Medika

Melanie, R. (2014). Analisis Pengaruh Sudut Posisi Tidur dan Tanda Vital pada pasien Gagal Jantung di Ruang Rawat Intensif RSUP Dr. Hasan Sadikin Bandung

Muttaqin, A. (2014). Pengantar Asuhan Keperawatan Klien dengan Gangguan Sistem Kardiovaskular. Jakarta: Salemba Medika

Nurlaela, Erika Sitta (2017). Upaya Penatalaksanaan Pola Nafas Tidak Efektif pada Pasien Congestive Heart
Failure. Surakarta: Salemba Medika

Nurarif, H., A \& Kusuma H, (2015). Aplikasi Asuhan Keperawatan Berdasarkan Diagnosa Medis \& NANDA NIC-NOC Edisi Revisi Jilid 2. Yogyakarta: Mediaction

Oktafany, \& Djausal, A. N. (2016). Gagal Jantung Kongestif. Jurnal Kedokteran. Vol. 5, No. 1

Rachma, Nur Laila (2014). Patomekanisme Penyakit Gagal Jantung Kongestif. Jurnal El-Hayah Vol 4, No.2

Rekam Medic RSUD Wates, (2019). Prevalensi Klien dengan Congestive Heart Failure. Yogyakarta

Silvana, S, K (2015). Posisi Fowler dan Semi Fowler. Vol 4 No 1, diunduh pada tanggal 5 Juli 2019

Surwatika Ira dan Peni Cahyati (2015). Analisis Faktor Yang Berpengaruh Terhadap Kualitas Tidur Pasien Gagal Jantung Di RSUD Kota Tasikmalaya. Jurnal Skolastik Keperawatan Vol. 1, No. 1

Tim Pokja SDKI DPP PPNI, (2016). Standar Diagnosis Keperawatan Indonesia : Definisi dan Indikator Diagnostik. Edisi 1. Jakarta Selatan : Dewan Pengurus Pusat PPNI 